\title{
DINAMIESE SPIERTOETSE VIR JONG MANS
}

N. WARNICH, B.Sc. Fisio. (U.S.)

S. IRWIN-CarRUThers, Nat. Dip. Physio. (Pta.), Onderwys Dip. Fisio. (Pta.)

In September 1972 is 'n verslag oor dinamiese spiertoetswaardes vir jong vrouens in die Suid-Afrikaanse Fisioterapie-Tydskrif gepubliseer.' Aangesien daar geen sodanige onlangse waardes vir jong mans in die literatuur gevind kon word nie is toetse deur ' $n$ finale jaarstudent van die Universiteit van Stellenbosch oor die volgende jaar uitgevoer. Beide gemiddelde waardes vir jong mans is vas gestel asook vergelykende waardes vir 'n groep wat aktief in sport deel neem. Die studie van dinamiese spiertoetswaardes vir $m$. quadriceps femoris is verder uitgebrei om vergelykende waardes vas te stel vir 'n kleiner groep proefpersone wat kniebeserings opgedoen het.

In Monster van 25 jong mans tussen die ouderdom Pan 18 tot 24 jaar is geneem uit mans-studente aan die Universiteit van Stellenbosch. Die studente is verteenwoordig van feitlik alle kursusse en het nagraadse sowel voorgraadse studente ingesluit. Van die proefpersone het slegs 12 aktief aan sport deelgeneem. Verskeie sportsoorte is verteenwoordig en die meerderheid van hierdie groep proefpersone het aan twee of meer sportsoorte deelgeneem.

\section{Metodes:}

Vir alle toetse is gebruik gemaak van die standaardaanvangshoudings wat deur Daniels, Williams en Worthingham $^{2}$ voorgestel is vir manuele toetsing van spiere wat beweging teen swaartekrag kan uitvoer. By alle proefpersone is van die dominante ledemaat gebruik gemaak by die uitvoer van die toetse. Ten einde die maksimale werkvermoë van die betrokke spiere to verkry is ligte opwarmingsoefeninge eers uitgevoer. Met die uitsondering van $\mathrm{mm}$. gluteus medius en minimus is die gewigte d.m.v. of 'n "barbell" of ' $n$ de Lormeskoen toegepas, soos deur die verskillende spiere vereis. Mm. gluteus medius en minimus is d.m.v. sandsakke getoets. Toetse vir die tien-herhalingsmaksimum (10 H.M.) en een-herhalingsmaksimum (1 H.M.) volgens die definisie van Gardiner $^{3}$ is daarna uitgevoer.

\section{ovindings:}

Die toetsresultate is soos onder getabelleer en ontleed (Fig. 1 en 2).

\begin{tabular}{lrrrr}
\hline Gewig in pond & $F_{\perp}$ & $X_{1}$ & $F_{1} X_{1}$ & $F_{1} X_{1}-X_{1}$ \\
\hline $10,00-15,00$ & 1 & 12,50 & 12 & 156 \\
$15,00-20,00$ & 1 & 17,50 & 17 & 306 \\
$20,00-25,00$ & 3 & 22,50 & 67 & 1518 \\
$25,00-30,00$ & 12 & 27,50 & 330 & 9075 \\
$30,00-35,00$ & 3 & 32,50 & 82 & 2268 \\
$35,00-40,00$ & 5 & 37,50 & 187 & 7031 \\
\hline
\end{tabular}

Rekenkundige Gemiddelde - 27,90 pd.

Standaardafwyking - 5,99

Fig. 1: m. Deltoideus (middel vesels) - 10 H.M.

\begin{tabular}{ccccc}
\hline Gewig in pond & $F_{1}$ & $X_{1}$ & $F_{1} X_{1}$ & $F_{1} X_{1}-X_{1}$ \\
\hline $20,00-25,00$ & 1 & 22,50 & 22 & 506 \\
$25,00-30,00$ & 5 & 27,50 & 137 & 3781 \\
$30,00-35,00$ & 8 & 32,50 & 260 & 8450 \\
$35,00-40,00$ & 5 & 37,50 & 187 & 7031 \\
$40,00-45,00$ & 6 & 42,50 & 255 & 10837 \\
\hline
\end{tabular}

Rekenkundige Gemiddelde - 34,50 pd.

Standaardaf'wyking $-5,83$

Fig. 2: m. Deltoideus (middel vesels) -1 H.M.

$\mathrm{Na}$ statistiese ontleding is die gemiddeldewaardes vir agt verskillende spiergroepe soos volg vasgestel (Fig. 3).

\begin{tabular}{|c|c|c|c|c|}
\hline Spiergroep & & & H.M. & 1 H.M. \\
\hline Rectus abdominis & & & 72,60 & 96,20 \\
\hline Middel deltoied & & & 27,90 & 34,50 \\
\hline Triceps ( + anconeus) & & & 39,10 & 44,50 \\
\hline Biceps (+ brachialis) & & $\ldots$ & 36,90 & 45,70 \\
\hline Gluteus maximus (+ ham & & & 43,70 & 59,30 \\
\hline Gluteus medius + minimus & $\ldots$ & $\ldots$ & 40,30 & 50,70 \\
\hline Quadriceps femoris & & $\begin{array}{l}\cdots \\
\cdots\end{array}$ & 74,60 & 93,80 \\
\hline Hampese $\ldots . .$. & $\cdots$ & $\cdots$ & 46,90 & 56,60 \\
\hline
\end{tabular}

Fig. 3: Geniddelde 10 H.M. en 1 H.M. waardes.

\section{Vergelykende waardes:}

In vergelyking met die groep wat aktief in sport deelgeneem het teenoor die onaktiewe proefpersone is die volgende resultate verkry (fig. 4). 'Deurgaans sal gelet word dat die ,aktiewe" proefpersone hoër waardes bereik het, met 'n minimale verskil van $1,46 \mathrm{pd}$. en 'n maksimale verskil van 12,50 pd. vir die tien-herhalingsmaksimum-waardes, en soortgelyke verskille vir die eenherhalingsmaksimum-waardes.

\begin{tabular}{|c|c|c|c|c|}
\hline Dinamiese toetse & \multicolumn{2}{|c|}{ Aktief } & \multicolumn{2}{|c|}{ Onaktief } \\
\hline Spiergroep & 10 H.M. & 1 H.M. & 10 H.M. & 1 H.M. \\
\hline $\begin{array}{l}\text { Rectus } \\
\text { abdominis }\end{array}$ & 73,25 & 98,38 & 68,73 & 93,88 \\
\hline $\begin{array}{c}\begin{array}{c}\text { Middel } \\
\text { deltoied } \\
\text { Triceps }\end{array} \quad \ldots \\
\end{array}$ & 27,50 & 34,08 & 26,00 & 33,19 \\
\hline $\begin{array}{l}\text { (+ anconeus) } \\
\text { Biceps }\end{array}$ & 40,33 & 48,63 & 34,89 & 41,72 \\
\hline $\begin{array}{l}\text { (+ brachialis) } \\
\text { Gluteus maximu }\end{array}$ & us 35,54 & 45,50 & 34,08 & 41,88 \\
\hline $\begin{array}{l}\text { (+hampese) } \\
\text { Gluteus medius }\end{array}$ & 45,41 & 59,00 & 40,27 & 55,58 \\
\hline $\begin{array}{l}\text { Gluteus medius } \\
\text { en minimus } \\
\text { Quadriceps }\end{array}$ & 41,16 & 49,29 & 38,92 & 48,61 \\
\hline femoris & 79,54 & 99,41 & 67,04 & 87,65 \\
\hline Hampese & 47,70 & 60,91 & 43,04 & 51,62 \\
\hline
\end{tabular}

Fig. 4: Vergelykende waardes vir aktiewe en onaktiewe groepe. 


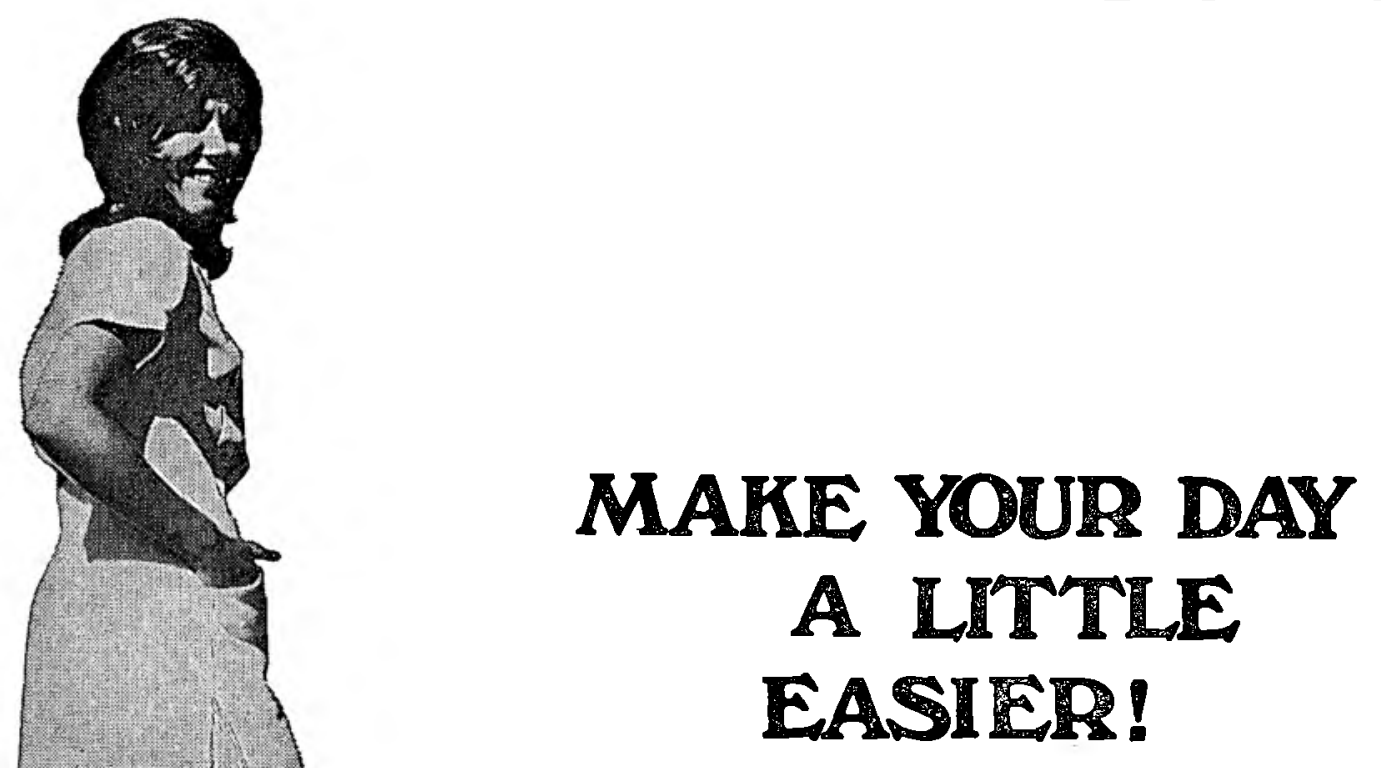

You physios are a hard-worked group, we know. In the day's work, environment and comfort become more and more important - and while there's not much we can do to help fix the background in which you work, you'll find a comfy, practical working rig in the new specialpurpose uniform we've designed with you in mind.

It's a continental style dress, with Bermuda-type shorts to match. A side vent in the skirt and the generous cut, mean that you'll work more easily, and feel comfortable right through the hard day.

Your option of short or long sleeves, in drip-dry, hard-wearing fabric... white or saxe blue. Sizes 32 to 42 .

Elegance and efficiency ... what more could you ask?

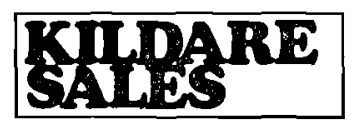

4th Floor, Pritchard House, 83 Pritchard Street, JOHANNESBURG. Telephone 23-4405.

87 Marion Avenue, Glenashley, DURBAN. Telephone 83-7226.

Fully illustrated catalogues and price lists of our full range are available free to you. Just drop us a postcard (P.O. Box 752, Johannesburg) or telephone 23-4405 any time, including nights, weekends and holidays. We're also happy to execute phone orders, of course. 
Viertien van die proefpersone het beserings opgedoen wat volgens hulle mening die uitvoer van sekere toetse kon belemmer. Onder dié persone is 'n kleiner groep van 6 uitgekies wal beserings in die omgewing van die kniegewrig opgedoen het. Die beserings het letsels van die menisci, ligamente en spiere ingesluit, waarvan geen onlangs plaasgevind het nie. Die waardes vir die quadriceps en hampees-spiere by hierdie groep proefpersone in vergelyking met die onbeseerde groep word in Fig. 5 uiteengesit.

\begin{tabular}{lrrrrr}
\hline Spiergroep & \multicolumn{2}{c}{ Beseerde groep } & \multicolumn{2}{c}{ Kontrole } \\
\hline & 10 H.M. & 1 H.M. & 10 H.M. & 1 H.M.M. \\
\hline Quadriceps & & & & & \\
temoris & $\ldots$ & 70,64 & 95,82 & 75,64 & 105,16 \\
Hampese & $\ldots$ & 44,45 & 54,35 & 47,93 & 57,14 \\
\hline
\end{tabular}

Fig. 5: Vergelykende waardes vir kniebeserings.

\section{ZEWWYSINGS:}

1. Irwin-Carruthers, S.: Dynamic Muscle Testing and Progressive Resistance Exercises, S.A. Tydskrif Fisioterapie, 28, 3, Sept. 1972.

2. Daniels, L., Williams, M., and Worthingham, C. (1969), "Muscle Testing, Techniques of Manual Examination", Philadelphia and London, W.B. Saunders Co.

3. Gardiner, M.D. (1960), "The Principles of Exercise Therapy", London, G. Bell and Sons, Ltd.

\section{SUMMARY :}

Dynamic muscle testing of eight different muscle groups was carried out on 25 young men between the ages of 18 and 24 years. Twelve of the subjects regularly participated in sport. The average values found for the 10 repetition maximum and the 1 repetition maximum are tabled. Comparative studies showed a significant difference in performance between those who actively participated in sport and those who did not. Past injury in the area of the muscle group being tested also affected performance.

\section{A. C. MILleR \& CO. ORTHOPAEDIC MECHANICIANS}

Technicians registered with S.A. Medical and Dental Council specialising in the following: ORTHOPAEDIC APPLIANCES, SURGICAL CORSETS, CERVICAL COLLARS, CHILDREN'S SHOES AND BOOTS, ARTIFICIAL LIMBS, LATEST IN PLASTIC MODIFICATION. HIRING AND SELLING OF HOSPITAL EQUIPMENT AND SICK ROOM REQUISITES, e.g. WHEEL CHAIRS, COMMODES, HOSPITAL BEDS, WALKING AIDS, TRACTION APPARATUS, etc.
Telephone 23-2496
P.O. Box 3412 275 Bree Street
Johannesburg

\section{VACANCIES \\ OTAGO POLYTECHNIC}

\section{DEPARTMENT OF PHYSIOTHERAPY}

Jreement has now been finalised on the transfer of the New Zealand School of Physiotherapy to the control of the Otago Polytechnic Council from 1 February, 1976. In anticipation of this transfer, and to provide for an increased staffing establishment, the Otago Polytechnic Council invites applications for the following position. Technical Institutes conditions of service will apply and applications should preferably be made on form E25/1, which is obtainable from all Technical Institutes in New Zealand and from the New Zealand Department of Education.

\section{HEAD OF DEPARTMENT OF PHYSIOTHERAPY}

\section{H.O.D. Grade I}

Salary $\$ 12448$ plus cost living allowance $\$ 156$.

The Head of Department selected by the Council of Otago Polytechnic must be well qualified both academically and by practical experience. Registration as a teacher of Physiotherapy or equivalent will be essential, together with a sound background of clinical experience, teaching and administration.

Applications close with the Secretary, Otago Polytechnic Council, Private Bag, Dunedin, New Zealand, at 9 a.m. on Monday, 30 June, 1975.

\section{RHODESIA PUBLIC SERVICES}

\section{MINISTRY OF HEALTH: PHYSIOTHERAPIST}

Applications are invited from suitably qualified and experienced persons for the vacant post of Physiotherapist in the Ministry of Health, Rhodesia.

The post is in the professional grade and the commencing salary depends upon qualifications and relevant experience. An initial Uniform Grant plus a monthly Uniform Maintenance Allowance will be paid to the incumbent of the post. A special allowance is also paid to Physiotherapists appointed in General and District Hospitals outside Salisbury and Bulawayo.

Salary: $\$ 2977 \times \$ 174$ to $\$ 4911$ per annum

(R3 605 x R209,50 to R5873 per annum, approximately).

Annual Bonus: An annual bonus is paid at the rate of $5 \%$ of pensionable emoluments each year, subject to a maximum of $\$ 300$ (approximately $\mathrm{R} 360$ ) to all officers in the service.

Conditions: The Ministry offers generous conditions of service, pension, medical aid facilities.

Leace: Annual, Vacational and Sick Leave.

Passage: Passage to Rhodesia will be paid for the successful applicant.

Applications stating age, marital status, qualifications, date of availability, should be addressed to: The Secretary for Health. P.O. Box 8204, Causeway, Salisbury, Rhodesia. 